\title{
Effects of Pediatric Training for Detecting Signs of Developmental Problems
}

Efeitos de Formação Pediátrica para Detecção de Sinais de Problemas de Desenvolvimento

Efectos de la Formación Pediátrica en la Detección de Señales de Problemas de Desarrollo

\section{Ana Silvia de Morais, Edna Márcia}

Koizume Bronzatto, Rogério Lerner

\& Maria Cristina Machado Kupfer

Universidade de São Paulo

http://dx.doi.org/10.1590/1982-370300252014 
Abstract: A multicenter study (2004-2008) of clinical Risk Indicators for Child Development (IRDI) created and validated 31 indicators that can be observed in the initial 18 months post birth, with a statistically significant ability to predict developmental problems and psychic risk. Pediatricians were trained to collect data using the instrument. We discuss what remained for the pediatricians by interviewing a pediatrician who attended the course. The interview was analyzed from an institutional discourse perspective, revealing an objective/subjective duality and a split between prior and acquired knowledge. The ward emergency scenario does not provide enough time for a guided look at the indicators; indicators associated with parental function had a greater impact. The course increased his pleasure in his clinical practice, although his prior knowledge was limited. We suggest investigating the extent and limits of the effects of IRDI-oriented training for medical practice.

Keywords: Professional education. Pediatrics. Child development. Discourse Analysis.

Resumo: De 2004 e 2008, a Pesquisa Multicêntrica de Indicadores Clínicos de Risco para o Desenvolvimento Infantil (IRDI) criou e validou 31 indicadores observáveis nos primeiros 18 meses de vida, com capacidade estatisticamente significativa de predição de problemas de desenvolvimento e predição de risco psíquico. Pediatras foram formados para coletar os dados. Este trabalho discute quais saberes mantiveram-se após sete anos, por meio de entrevista a um pediatra que participou da formação. O material foi submetido a uma análise institucional do discurso. Os resultados apontam que a especialidade técnica prévia do profissional influenciou na forma de apropriação dos indicadores. Há dualidade objetivo/ subjetivo e cisão entre o conhecimento prévio e o adquirido na formação. Indicadores foram descaracterizados como ferramenta suplementar reveladora de doenças do hábito. O cenário de urgência da enfermaria não coincide com o tempo necessário para um olhar orientado pelo IRDI; indicadores ligados à função paterna tiveram maior impacto. A formação levou a um ganho de prazer com a realização de consultas. Porém, a ressignificação do conhecimento prévio foi limitada. Sugerem-se investigações a respeito da extensão e dos limites dos efeitos de uma formação orientada pelos IRDIs para a prática médica.

Palavras-chave: Formação profissional. Pediatria. Desenvolvimento infantil. Análise do Discurso.

Resumen: Entre 2004 y 2008, la Investigación Multicéntrica de Indicadores Clínicos de Riesgo para el Desarrollo Infantil (IRDI, por su sigla en portugués) creó y validó 31 indicadores observables en los primeros 18 meses de vida, con capacidad predictiva, estadísticamente significativa, de problemas de desarrollo y riesgo psíquico. Pediatras fueron formados para recolectar los datos. Se discuten cuáles saberes se mantuvieron siete años después de la formación por medio de entrevista a un pediatra que participó del curso. La entrevista fue sometida a un análisis institucional del discurso. Los resultados señalan que la especialidad técnica del profesional influenció en la forma de apropiación de los indicadores. Hubo una dualidad objetivo/ subjetivo y en algunas situaciones, se tomaron los indicadores como herramienta reveladora de "enfermedades del hábito", perdiendo así su carácter. Se evidenció que el escenario de emergencia de la enfermería no coincide con el tiempo necesario para una mirada orientada por el IRDI. Indicadores vinculados a la función paterna tuvieron mayor impacto. La formación hizo que las consultas médicas fueran más largas y placenteras, sin embargo, la resignificación del conocimiento previo fue limitada. Se sugieren investigaciones acerca de la extensión y límites de los efectos de la formación requerida por los IRDIs en la práctica médica.

Palabras claves: Formación profesional. Pediatría. Desarrollo infantil. Análisis del discurso. 


\section{Introduction}

In public health, child care focuses on growth and development, guiding clinical practice and routine procedures of pediatricians and other professionals (Ministério da Saúde, 1984). One objective of this approach is to identify risks and pathological trends. By including mental health as a line of action, the Agenda de Compromissos para a Saúde Integral da Criança e Redução da Mortalidade Infantil [Agenda for Commitment to Comprehensive Child Health and Reduction of Infant Mortality] (Ministério da Saúde, 2004) states that "(...) professionals must be able to identify and refer children who need intervention in cases where there are indicative symptoms of autism, psychosis or more severe neurosis" (p. 31).

Several studies indicate the need of lowering the age of diagnosis, prompt referrals and interventions, early detection of signs of mental disorder, including them in public health services, and providing families with professional education (Mandell, Novak \& Zubritsky, 2005; Barbaresi, Katusic \& Voigt, 2006; Dosreis \& Weiner, 2006; Holzer et al., 2006; Myers \& Johnson, 2007; Ingleses, 2009).

There is evidence for most pediatricians' reluctance to provide treatment for children with mental impairments, although they agree it is necessary and realize their responsibility in referring these cases appropriately (Stein et al, 2008).

Gadomski et al. (2010) highlighted the fact that physicians are reluctant to diagnose mental disorders and do not refer patients to mental health services. This is possibly because of the lack of time and training to accurately diagnose mental health disorders. When diagnosed, primary care services are not able to cover this demand. There is a need to provide additional training to physicians for tackling the problems of children with mental health problems.

Crane and Winsler (2008) reported that according to the American Academy of Pediatrics - AAP, $30 \%$ of general practitioners follow polices for the detection of developmental delays. They cited the study carried out in 2004 by Laura Sices and collaborators with 800 pediatricians in the United States, stating that parental concerns do not influence referrals and instead use the "wait and watch" method. The families assume that pediatricians are trained to recognize the developmental problems (Crane \& Winsler, 2008).

According to Stein et al. (2008), changes in training regarding the relevance of psychological issues for patients' health can influence the attitudes of physicians. They noted the importance of experienced senior pediatricians being aware of the fact that they had to teach residents that they were responsible for the worsening of mental health problems in case of not providing quick referrals to appropriate services.

Dulmen and Holl (2000) indicated that the teachings during pediatric residency might influence future professional performance. Residents do encounter mental health problems in their training, but not all of them realize their responsibility. Well-trained professionals are required to treat these issues and propose proper referral. Those physicians who go through verbal exploration and observational training offer more opportunities for their patients to talk about their issues, concerns and worries, providing the professional a longer period to observe the patient dynamics. They detect psychosocial problems, gain flexibility and willingness to include children and parents in the communicative interaction of the clinical service, and become more aware of their needs. 
1 A National Research Group (a.k.a. GNP) convened by Maria Cristina Machado Kupfer, PhD, was created to develop this research. The group comprised Leda M. Fischer Bernardino, PhD, PUC, Curitiba; Paula Rocha and Elizabeth Cavalcante, CPPL of Recife; Domingos Paulo Infante, Lina G. Martins de Oliveira and $\mathrm{M}$.

Cecilia Casagrande from São Paulo; Daniele Wanderley from Salvador; Lea

M. Sales, PhD, Federal University of Pará; Professor Regina M. R. Stellina,

PhD, UNIFOR from For-

taleza; Flavia Dutra from

Brasilia; Otávio Souza, PhD, from Rio de Janeiro;

Silvia Molina from Porto

Alegre, with technical coordination of M. Eugenia Pesaro, scientific coordination of Alfredo Jerusalinsky, $\mathrm{PhD}$, and national scientific coordination of M. Cristina M. Kupfer, PhD.

2 For a detailed discussion about the merging of these two types of knowledge, see the thesis of Mary Eugenia Pesaro: "Scope and

limits of theoretical and methodological multicenter study of clinical risk indicators for child development"

(Pesaro, 2010).
Pediatric organizations have been developing instruments and guidelines to help clinicians to identify, treat and manage children with mental problems.

In Brazil, there is a lack of professional communication skills and competencies needed to assess child development in health units (Figueiras, Puccini, Silva \& Pedromônico, 2003; Nóbrega, Jorge Valdès \& Silva, 2003; Figueiredo \& Mello, 2003; Braga \& Avila, 2004; Vasconcelos, Silveira, Eulálio \& Medeiros, 2009; Oliveira \& Cadette, 2009), compromising the objectives of child health policies.

Therefore, health professionals should be able to assess the possible signs of risk or psychopathology tendency in the mentally ill child. This demands the understanding of the relationship with the caregiver, because this communications facilitates the assessment of developmental delays, and neurological and motors events in the child's life. (Wanderley, Weise \& Brant, 2008; Carvalho, Silva, Grisi \& Escobar, 2008).

\section{Pediatrician education in the IRDI multicenter research}

In 1999, the Grupo Nacional de Pesquisadores [National Group of Researchers] (GNP) ${ }^{1}$ designed 31 Clinical Risk Indicators for Child Development (IRDI) based on psychoanalytic concepts as well as on developmental psychology and neurology at the request of the Ministry of Health, sponsored by São Paulo Research Foundation (FAPESP) and the National Council for Scientific and Technological Development (CNPq). These indicators are used to evaluate children up to 18 months of life with their parents during pediatric consultations (Kupfer, Jerusalinsky, Bernardino, Wanderley, Rocha, Molina et al., 2009; Lerner \& Kupfer, 2008). The lack of two or more indicators signals the risk of developmental problems.
In 2004, pediatricians were trained to use IRDI to "sensitize pediatricians to the idea that some developmental aspects result from fundamental subjectivizing operations in course in early childhood, so that developmental problems might be an evidence of problems in such an operation (Lerner, Cullere-Crespin \& Kupfer, 2011)." Two meetings happened within an interval of eight months, comprising 90 pediatricians from 11 health centers in 9 Brazilian cities. Psychoanalysts followed the training and the implementation of the protocol by pediatricians. The articulation between what was exposed for pediatricians and their clinical experience was encouraged (Lerner, Cullere-Crespin \& Kupfer, 2011). IRDI stands out for its simplicity and fast application and it shows a risk trend, not a pathology specificantion, allowing a comprehensive assessment of the child.

Researches that use IRDIs express areas such as pediatrics and psychiatry, among others, in a productive debate bringing theoretical impasses to light ${ }^{2}$. One of them approaches Psychoanalysis and Education when referring to the transmission of principles arising from psychoanalysis to other fields, such as public health-with aspects of collectiveness in contrast with the particularity that psychoanalytic theory considers.

By proposing ethical-clinical tools for teachers' education, Almeida (2006) stands for a transmission of psychoanalysis in extension (teaching situations, dissemination, and distribution), because minimum conditions are developed. One of them would be the objective of this proposal: promoting a subjective change in the participants, in their relation with ideals and with the real of their practice - creation and pleasure in place of anguish.

The present article aims to raise a discussion about the effects of an encounter between 
3 The notion of institutional actor was used by

Albuquerque (1978) to treat theater as a metaphor for the relationship occurring between roles that agents play in the institutional setting. psychoanalysis and public health regarding professional's education and the transmission of psychoanalytic notions to those who know little or nothing about it. To this end, we interviewed a pediatrician who had attended the course for IRDI use in 2004. The interview was conducted in 2010.

The guiding questions were: Was there any apprehension of knowledge by pediatricians who have attended the course? How did such apprehension happen and how does it appear in his practice? The method used was the institutional discourse analysis (Guirado, 1986, 1995, 2000, Guirado \& Lerner, 2007).

\section{Method - On Institutional Discourse Analysis}

There are many matters by which this method works, but the perspective of discourse articulating psychic and institutional scopes remains the same. Research has been carried out on how professionals (psychologists or not) act in institutions such as schools (Aquino, 1995; Ferraz, 2000; Marques, 1999), psychosocial care centers (Lerner, 2006a,b); Souza, 2003), partial hospitalization programs (Vechi, 2003), volunteer groups in specific clinics within hospitals (Ortiz, 2001), psychological expertise requested by members of the Judiciary (Alves, 2002; Travieso, 2001), among others. Besides professional performance in institutions, processes directed to the Federal Council of Psychology (Galvão, 2000), laws that governed the constitution of asylums and psychiatric hospitals in Brazil (De Bellis, 2004), and homeless people (Serrano, 2004; Silva, 2002) have also been researched.

The initial equation considers two levels: the relations in their affective dimension (traditional concern of psychology) and institutions (traditional concern of sociology). The conception of subjectivity is that one of a subject constituted in and constitutive of the concrete institutional relationships. Any institutional actor ${ }^{3}$ has his intervention constituted

by crossovers and reissues of occupied and delegated places, considering his personal history and that of the institution. [In discourse], representations reveal and conceal, recognize and ignore their origins. They immediately outwit their instituting structure. (Guirado, 1995/2006, p. 53)

The subject is considered, in the same act, a support and an effect of discourse, beyond the scope of individual or intrapsychic aspects, but it is not confused with the consideration that sociology and linguistics make about the subject. The aims are
contributing to the understanding of how things happen, how specific or individual concrete relationships are constituted, and how these relation- ships end up being recognized or ignored in the imaginary movement that is set up in these relationships. (...) contributing to the understand- ing of how places in the relations between attendants and patients are distributed and which subjects recog- nize themselves in these relationships. (Guirado, 1995/2006, p. 53).

The goal is neither "psychologizing" nor "dissolving" the notion of subject. It is about analyzing the discourse to check singularities and regularities.

We quoted expressions and extracts of the interviewee's discourse that guided us in thinking about how indicators were apprehended. If our inquiries still extended to the collectivity, it is because we hoped it to guide us in the discussion about ways and challenges for the next training initiative for health professionals, although they are discussed here from a singular particular experience. 


\section{Results and Discussion}

The analysis of the interview showed the effects of IRDI course to pediatric practice, however, it explained the influence of medical, technical, and specialized education in how the indicators were assimilated, showing the weight of infant care practice history.

For our interviewee, the contact with the indicators occurred in 2004 during IRDI research, along with the rest of the team from the ambulatory of Hospital Universitário (HU) - department wherein he worked until 2006. He mentions the experience as a "mind widening" on child evaluation and the acquiring insight at the "child's interaction with the mother." He said that an objective assessment of child development, "historically, has always been part of a pediatricians education, training," focusing mainly at the motor gains and the neurological development of the infant. However, the influence of aspects such as personal background and professional path, including its subspecialties, seems to print a specific conformation to this new understanding of the child. Besides the residency in pediatrics, the interviewee also had a specialization degree in general nursing-an area he was currently working in - and in child hospitalization, both known for emergency situations. In the HU ward, he received patients from the Emergency Room or the Intensive Care Unit (ICU), of which he said, "they already come with a certain disease, established or identified in these two departments." His path from the outpatient clinic to the ward, added to his sub-specializations, seemed to emphasize the focus of the disease in his practice, as it marked the institutional spot occupied by the agent, whose function was "to initiate or maintain a treatment, depending on the disease."

To the current pediatric education, influenced by the increasing specialization and expansion of knowledge, the interviewee opposed the "old training," in which the professional "played the doctor, the nutritionist, the psychologist, ...absolutely everything." Thus, the practice of a "more intensive clinic" could be performed, according to the interviewee, in the private clinic.

Interviewee (I): Then, at the clinic we try the most to exhaust our social worker, nutritionist, psychologist, and when we detect something that goes beyond what we feel or what we are trained for, we refer the patient. This limit depends on each individual.

The excerpt above opens a possibility to a more sensitive practice about psychic matters, but besides reducing it to a specific setting, he considered it at the same time at a different clinical practice setting, a change to previous established knowledge. There seems to be no possibility of a bonding between a new knowledge and a prior knowledge to produce something different that has not belonged, in his view, to another specialty yet. What vision of clinic would be implied here? And how is it articulated with the indicators, whose purpose is to involve health professionals in early detection of social bond disorders, from his own practice?

When talking about procedures performed with the patient, from the interview to treatment progression, the interviewee emphasized the collective character of the intervention. The repetitive use of the pronouns we/us in his report indicated a discourse anchored on the relevance of the institutional group to which he was connected, that did not give room for his subjectivity in the constitution of the scene where, in the case of IRDI, the pair mother/infant were considered.

I: When the patient arrives, we interview the patient. When I say we, I mean someone from the team, sometimes more than one person examines the 
disease proposal, the diagnostics, and we also have the possibility to check some other things.

\section{Between the disease and the "habits," what is the place for IRDIs?}

The previous education of professionals also leaves its mark in the relation that the interviewee establishes with his patients. The division of the patient regarding organic, psychic, developmental, and relational aspects - a result of the segmentation of knowledge - interferes in the professional implication to the order of the subject of desire. In moments when the professional tends to consider other treatment options than those for identified organic diseases, that could make him consider relating it to IRDI, his discourse goes in another direction, persisting in the organic aspect of the disease.

$\mathrm{I}:(\ldots)$ in the ward we also have the possibility to check some other serious things that the patient has, and that could be even related to hospitalization, an anemia, that might be a factor that is predisposing an immunity deficiency, or a developmental...., then we detect other problems that might not be the main problem so we can act on these other issues that might be secondary.

It is important to highlight the interruption of speech in the word "developmental," which evokes "other secondary issues." It means that development is secondary, whereas "the main" issue seems to be the organic disease. They would be aspects of different orders, whose possible relationships do not seem to be considered.

It is also likely to find in the discourse the split between what he considered to be the child's illness and what he understands to be evaluated by IRDI. He kept them apart, not considering that diseases and psychic distress conditions might be related. It seems to be a causal thinking: what causes the child's behavior, the organic disease or what IRDI assesses, an "everyday thing, the usual?" Behavior would be then divided according to its cause: disease or habits. From this point of view, IRDI would be a habit assessment instrument. Such a division limits the places the indicator could be used at:

I: In the ward, as we receive a sick child, the difficulty is to know if the child is in that condition, you know, sleeping more, crying more, keeping very attached to the mother for being sick, or simply because this is an everyday thing, the usual. In the ward, it is not possible to make this IRDI assessment, but the circumstance is quite different. In an outpatient clinic, the child is going through a situation, he might be in with a cold, something less serious, but his reactions are surely closer to those when the child is at home rather than when he is hospitalized or in the emergency room. In this sense, we feel unable to use these indicators as we used in the outpatient clinic.

Given that the emergence characterizes the institutional setting of the ward, it does not seem to be the opening to the scope of mental suffering integrated to the general condition of the child. Far beyond the divisions that medical education can give to the apprehension of the indicators, the speech of the interviewee points out that the urgency time does not match with the time of an indicator - oriented look. In discussion on research methodology and psychoanalysis, Dunker, Voltolini e Jerusalinsky (2008) noted that in the reports of IRDI day-to-day research, it was likely to find an interesting effect of this experience. As a "psychoanalytic contamination of the medical field," it seems that consultation time has been extended among the participating physicians. 
It points to the impact in their practice of the analytical discourse and the time of the subject-a time of delay and expectance, as proved by the analytical experience.

\section{Fatherhood as a means of producing a unique knowledge}

Thus, it is amid this context of the disease as an organic matter, predominantly, that the formation of IRDI lies on, keeping as a challenge the development of another kind of look in the professional practice. In relation to the pediatrician interviewed, the way indicators affected his work refers to the weight of the fragmented scientific discourse and of the technique, although the path of a personal experience seems to have created an opening for a unique apprehension.

The indicators were considered by the respondent as a task to be fulfilled for institutional reasons, a contribution to the university and as an extra working instrument, an addition to obtain a more complete picture of the child:

I: So, we try to check the child in the most comprehensive aspect that we can, so that this work with IRDI has added an extra parameter in what we understand about the child. (...) We took this as one more point to be observed by the pediatrician to upgrade his comprehension of what the child is and what might happen and should be checked in the child.

I: It is a matter of more instruments to observe, to ask, to detect some situations of diseases early, non-organic causes, and psychic diseases in the child.

I: It opened a prospect of a "plus" that, in a non-organized manner as in the project, we have already known about it, so it would be interesting to know which results of the most important indicators we haven't had access to.
The insistence of the association of IRDI with "a plus" for the practice suggests that the core of the fragmented scientific discourse remains after the IRDI course; more than that, the indicators are apprehended through a way of doing additional and overlapping tasks and knowledge that intend to assess the child in his totality.

Note, also, the ambivalence between the efforts to give rise to less objective questions that would be, he said, akin to pediatrics, and to the objectivity physicians "like to have."

I: We might have some more objective instruments, because physicians like to have certain objectivity, right? Apart from the psychiatrist, I think the pediatrician is the one who tries harder to see the less objective aspects. Of course, these instruments help us a lot. Some facilities are always welcome to our daily work. I think IRDI project would be useful as an instrument, I end up taking a few shots, using a few things I saw in IRDI, but in fact it would be ideal if I knew exactly which the most important indicators were.

Through the excerpts analyzed, we note that the indicators were understood by the pediatrician as capable of evaluating an associated symptomatic condition with no relation to other symptomatic conditions under an organogenic perspective, sometimes they are even related to "habit" diseases. However, it can be said that the training course had an impact on the interviewee, which is proved when he can recall some of the indicators, such as those related to the observation of elements like the eye gazing and the mother-infant relationship speech (motherese) in:

Another thing we check is the eye gazing, you know, if the child is looking for the mother, it depends on the age, if the child can look for. If the child is looking for the mother, if the mother is looking 
for the child, for how long it happens, the intensity of eye gazing, we use it as a parameter as well. Oh, I remembered, if the mother talks to the child.

A higher incidence of IRDI on the interviewee, in a way it could generate effects of repositioning, and it seems to have occurred in indicators related to the paternal function, which he cited most frequently. This probably occurred because the knowledge involved in the indicators, regarding the psychic constitution of the infant through the bond with their caregivers, father and mother especially, resonated in the interviewee's own fatherhood experience, shortly after his participation in the multicentric research:

I: Well, people say that things do not happen by chance; maybe I needed it to be ready as a father (laughs).

I: Well, because I'm talking about my private life, my wife got pregnant, right after this project. So, there are several things that we came to value in a consultation, we never valued before. I wonder, I think we cannot say that we are totally free of something, an experience we've passed through, especially a training course, so I think I had some input from IRDI project, besides the fact that I became a father, and I try to be the most participative father I can be.

The association between IRDI and parenthood, trying to give a new meaning to both of them, would not be just what a transmission driven by psychoanalysis enables? That is, a unique apprehension of knowledge that always goes through the questions of the desire of those who submit to such transmission. Even if the answer is positive, the question of how it appears in professional practice remains. Authors using a clinical approach to psychotherapy applied to the analysis of professional practices (especially teachers) regard this as one of the premises of such strategy, the articulation between professional and personal areas (Almeida, 2009).

What followed the reference to becoming a father was the interruption of his discourse on the clinic practice. From that moment on, he began to relate the increased attention to "nonobjective issues" as a result only of parenthood.

I: What I saw here I tried to apply in my office. Because things were fresh, the things I saw in the morning I put in practice in the afternoon, it was much easier to apply. Then there was a gap of about four or five years there, even more. I stopped in 2003, 2004 (he wanders a little, quietly) I know I came back to office practice, here I have been for about six months. So, what I do at the office now, the issues I consider important have changed dramatically, in part I believe there is something to do with the IRDI project, but obviously being a father impacts our lives much more and so we end up transferring all these directly to the office practice, you know.

Does he believe that IRDI assessment must occur formally - as in the time of the research - to produce effects on his practice? Here we have the concept of an application related to training instead of a knowledge apprehension.

\section{The IRDIs and pediatric practice}

What was then the consequence of IRDI training course to the professional performance of our interviewee, to his pediatric practice?

With IRDI assessment, some observations that used to occur have gained new meaning: the neurological point of view became "psychological."

I: I remember I had this knowledge: if the child speaks and the mother talks to the child, so we check for it too. I think we have already checked this before 
IRDI. But now we began to see how a parameter of its non-occurrence can be a warning sign.

I: As a matter of fact, if the child is being stimulated, if the child is listening to what the mother says, if he can repeat, it indicates much more of a neurological development and language rather than a psychological illness.

Another important change concerns the positioning of the pediatrician in the office practice. Through an oversight, something of the doctor-patient relationship appears after the IRDI course, something that he eventually drew, placing it in a less technical perspective, to be associated with pleasure.

I: So one thing was., one clear thing is that spending more time in consultation, paying attention to the doctor-patient rela[tion], child-mother relationship, within the child's development.

I: The mother eventually realizes that we care about her relationship with the child, how life has changed after becoming a mother, then it certainly creates an empathy for the mother, it also ends up improving, for sure today my consultations are less technical, it looks like I'm talking with a friend, a more pleasant conversation, talking about the day-to-day, but it looks like I'm more like playing, quotation marks, than working. I enjoy it better.

In this fragment, a new relationship with medical knowledge is explained, wherein there is place for fun and pleasure. This finding is consistent with the literature on the transmission of psychoanalysis to other fields, suggesting an important effect enabled by the IRDI course. Although the formation of the multicenter study did not follow a clinical setting, similar to what was proposed by Baietto and Gadeau to education (2002, apud Almeida, 2009), we can say that some effects might have been mobilized as a "passage through two ways of understanding practice: the first one, technical, 'acquired,' based on knowledge and, the other one, less strict to the expert knowledge, wherein the subject engages in a different way, in his own way of speaking and listening."

From his practice, Almeida (2006) states that one of the transmission effects of psychoanalysis to educators is precisely the possibility of living the educational relationship as a unique and creative experience, less fraught with narcissistic ideals and therefore more enjoyable.

\section{Conclusions}

The discussion of educational services aimed at pediatricians would refer to, as the result of the discourse analysis presented, a discussion of medical academic education. Posternak (2000) highlighted the difficulty of pediatricians to integrate the psyche of the child to family and social contexts, analyzing it in relation to the onset of symptoms or of organic disease. The author argues that this is due primarily to the fact that medical science does not have as its purpose the relational aspect. The physician's approach on issues as that of the Cartesian method is not enough becomes difficult, creating anxiety. The author presents two hypotheses about this problem. The first one relates the pediatrician's difficulty with the unconscious motivations of his vocation, which constitute a source of energy that, sublimated, reconcile pleasure, and social mandate. Among the forces acting in the choice for pediatrics, there are: the identification with the child; the repair concerning the ambivalence and the aggression that the relationship with parents leads to; and the power that the medical knowledge is legitimate, especially regarding the child's parents.

The second hypothesis relates to the peculiarities of medical education. The introduction of the hard 
sciences (physics, chemistry, and statistics) in the initial period of the course reflects the ideal of medical tasks: accuracy, scientific rigor, and the value of objectivity, and the relations of cause and effect. Advancing to the anatomy, the kind of thinking encouraged rests on the observation of what can be seen and palpated. The observation model is the corpse on the dissecting table. This whole scenario would promote, in general, a detachment of the physician in the relationship and a lack of preparation of this doctor with the management of psychiatric symptoms. One way to meet this educational bias would be the understanding of the pediatricians not only as the child's doctor, but the family physician, focusing on health care at the heart of the web of family relationships - place of feelings and conflicts (Posternak, 2000).

From the medical psychology with psychoanalytic theoretical support, Souza (2001) recounted her experience of teaching a course about the reflection on medical practice. From her classes, she recorded and discussed the discourse of 14 medical students about the conflicts in the apprehension of medical discourse in the early clinical practice. The discourses were grouped into four themes: devaluation of psychological distress; denial of the symbolic body; engendering of a technical identity; and subject experience in the process of pair identification. The author's conclusion was that the very knowledge produced by the group discussion tends to be dominated, disqualified, because the discursive practice is limited by the established medical order.

The discourse analysis revealed that the course regarding the IRDIs suffered from domination or discipline by the interviewee's prior discourse. Perhaps this is a risk that courses of this nature always take.
Regarding the effects of training - some of them unexpected or unintended - , although there were decisive signs that the interviewee was affected, it is important to consider that beyond the extra time he said he started spending, he also said he could not remember possible directions or hypothesis changes influenced by IRDI in his work. The more time spent by the pediatrician is no small feat, as well as the incorporation of pleasure in work, as opposed to a predominantly technical relationship, and the entanglement of a personal experience such as parenthood, with the unmistakable mark left by the indicators related to the paternal function. However, how to generate a range of effects on professional practice, enabling a referral or a reflection that does not represent a split between prior knowledge and new knowledge? It is the need for this new step that this research seems to point at and remains open.

At the heart of our discussion there is the question about the possibility and the characteristics needed for an educational experience in public health, oriented by psychoanalysis, resulting in the production of knowledge about the human constitution. A clue is given by Mezan (2002), when warning that the logical formalization of psychoanalytic theory is different from a psychoanalytic study of psychoanalysis. Whereas the first corresponds to the learning, the second corresponds to the appropriation. Although the focus is the education in psychoanalysis for psychoanalysts, we are interested in the discussion of an educational practice that instead of imposing a certain reading, inspire, and collaborate to "create a modus operandi that serves as a tool to develop and sustain their own way of thinking and working" (p. 202), and that, at last, operates in favor of the apprehension. 


\section{Ana Silvia de Morais}

Mestre em Psicologia Escolar e do Desenvolvimento Humano pela Universidade de São Paulo, São Paulo - SP. Brasil.

E-mail: anasmorais@hotmail.com

\section{Edna Márcia Koizume Bronzatto}

Mestre em Psicologia Escolar e do Desenvolvimento Humano pela Universidade de São Paulo, São Paulo - SP. Brasil.

E-mail: marcia.koizume@ig.com.br

\section{Rogério Lerner}

Doutor em Psicologia Escolar e do Desenvolvimento Humano pela Universidade de São Paulo, São Paulo - SP. Brasil. Docente da Universidade de São Paulo, São Paulo - SP. Brasil.

E-mail: rogerlerner@usp.br

\section{Maria Cristina Machado Kupfer}

Doutorado em Psicologia Escolar e do Desenvolvimento Humano pela Universidade de São Paulo, São Paulo - SP. Brasil.

E-mail: mckupfer@usp.br

\section{Endereço para envio de correspondência:}

Rua Girassol, 1540, apto 102, Vila Madalena. CEP: 05433-002. São Paulo - SP. Brasil.

Recebido 06/03/2014, Aprovado 23/01/2015. 
Albuquerque, J. A. G. (1978). Metáforas da desordem: o contexto social da doença mental. Rio de Janeiro, RJ: Paz e Terra.

Almeida, S. F. C. (2006). Transmissão da psicanálise a educadores: do ideal pedagógico ao real da (trans)missão educativa. Estilos da clínica, São Paulo, 11(21), 14-23.

Almeida, S. F. C. (2009). Desafios na formação clínica de professores: entre cuidado, o ensino e a transmissão. In Formação de Profissionais e a Criança-Sujeito, 7, 2008, São Paulo. Retrieved from http:// www.proceedings.scielo.br/scielo.php? script=sci_arttext\&pid=MSC0000000032 008000100006\& Ing=en\&nrm=iso>

Alves, M. L. D. (2002). Uma prática discursiva no encontro entre a psicanálise e o direito. Thesis. Instituto de Psicologia, Universidade de São Paulo, São Paulo, SP.

Aquino, J. R. G. (1995). Relação professor-aluno: uma leitura institucional. Thesis. Instituto de Psicologia, Universidade de São Paulo, São Paulo, SP.

Barbaresi, W. J., Katusic, S. K., \& Voigt, R. G. (2006). Autism: A review of the state of the science for pediatric primary health care clinicians. Archives of Pediatrics \& Adolescent Medicine, 160(11), 1167-1175.

Braga, M. R., \& Ávila, L. A. (2004). Detecção dos transtornos invasivos na criança: perspectiva das mães. Rev Latino-am Enfermagem, 12(6), 884-889.

Carvalho, A. L., Silva, L. F., Grisi, S. J. F. E., \& Escobar, A. M. U. (2008). Clinical indicators of child development in the capitals of nine Brazilian states: the influence of regional cultural factors. Clinics (São Paulo), 63, 51-58.

Crane, J. L., \& Winsler, A. (2008). Early autism detecion. implications for pediatric practice and public policy. Journal of Disability Policy Studies, 18(4), 245-253.

De Bellis, A. C. (2004). Liberdade e vigilância: o lugar da alta no discurso legal sobre a interna ção psiquiátrica. Dissertação de Mestrado, Instituto de Psicologia, Universidade de São Paulo, São Paulo.
Dosreis, S., \& Weiner, C. L. (2006). Autism spectrumdisorderscreeningandmanagement practices among general pediatric providers. Journal of Developmental and Behavioral Pediatrics, 27(2 Suppl S), S88-S94.

Dulmen, A. M., \& Holl, R. A. (2000). Effects of continuing pediatric education in interpersonal communication skills. European Journal Pediatric. 159, 489-495.

Dunker, C. I. L.; Voltolini, R. \& Jerusalinsky, A. N. (2008). Metodologia de pesquisa e psicanálise. In R. Lerner \& M. C. M. Kupfer (Eds.). (2008), Psicanálise com crianças: Clínica e pesquisa (pp. 63-91). São Paulo: Escuta.

Ferraz, L. M. (2000). Auto-imagem em cena: o discurso de jovens e adultos que retornam à escola. Dissertation. Instituto de Psicologia, Universidade de São Paulo, São Paulo, SP.

Figueiras, A. C. M, Puccini, R. F., Silva, E. M. K. S., \& Pedromônico, M. R. M (2003). Evaluation of practices and knowledge of professionals in primary health care on child development surveillance. Cadernos de Saúde Pública, 19(6), 691-1699.

Figueiredo, G. L. A., \& Mello, D. F. (2003). A prática de enfermagem na atenção à saúde da criança em unidade básica de saúde. Revista Latino-americana de Enfermagem, 11(4), 544-551.

Gadomski, A., Wisson, L. S., Slade, E., \& Jenkins, P. (2010). Training clinicians in mental health communication skills: impacto in primary care utilization. Academic Pediatric Association, 10(5), 346-352.

Galvão, L. F. (2000) Práticas alternativas?: Uma leitura institucional da questão. Dissertation. Instituto de Psicologia, Universidade de São Paulo, São Paulo, SP.

Guirado, M. (1986). Instituição e relações afetivas: o vínculo com o abandono. São Paulo, SP: Summus.

Guirado, M. (1995). Psicanálise e análise do discurso. São Paulo, SP: Summus.

Guirado, M. (2000). A clínica psicanalítica na sombra do discurso. São Paulo, SP: Casa do Psicólogo. 
Guirado, M. (2006). Psicanálise e análise do discurso: Matrizes institucionais do sujeito psíquico (2a. ed. rev. ampl.). São Paulo. SP: EPU. (Trabalho original publicado em 1995).

Guirado, M. \& Lerner, R. (Eds.). (2007). Psicologia, pesquisa e clínica: Por uma análise institucional do discurso. São Paulo: FAPESP.

Holzer, L., Mihaileseu, R., Rodrigues-Degaeff, C., Junier, L., Muller-Nix, C., Halfon, O., et al. (2006). Community introduction of practice parameters for autistic spectrum disorders: advancing early recognition. Journal of Autism and Developmental Disorders, 36(2), 249-262.

Ingleses, M.D. (2009) Caring for children with autism spectrum disorder, Part II: Screening, diagnosis, and management. Journal of Pediatric Nursing, 24(1), 49-59.

Kupfer, M. C. M., Jerusalinsky, A. N., Bernardino, L. M. F., Wanderley, D., Rocha, P. S. B., Molina, S. E. et al. (2009). Valor preditivo de indicadores clínicos de risco para o desenvolvimento infantil: um estudo a partir da teoria psicanalítica. Latin American Journal of Fundamental Psychopathology, 6(1), 48-68.

Lerner, R. (2006a). A psicanálise no discurso de agentes de saúde mental. São Paulo, SP: Casa do Psicólogo.

Lerner, R. (2006b). Counter-transference discursive matrix: ethical discussion concerning the therapeutic accompaniment and mental health institutions. Psyche (Sao Paulo), 10(18), 21-28.

Lerner, R.; Kupfer, M.C.M. (Org.). (2008). Psicanálise com crianças: Clínica e pesquisa. São Paulo, SP: Escuta.

Lerner, R.; Cullere-Crespin, G.; Kupfer, M.C.M. (2011). Formação de pediatras para detecção de riscos de transtornos de desenvolvimento: da especialização à abertura para a constituição subjetiva da criança. In S. F. C. Almeida \& M. C. M. Kupfer, (Org.), A psicanálise e o trabalho com a criança sujeito (pp. 71-81). Rio de Janeiro, RJ: WAK.

Mandell, D. S.; Novak, M. M., \& Zubritsky, C. D. (2005). Factors associated with age of diagnosis among children with autism spectrum disorders. Pediatrics, 116(6), 1480-1486.

Marques, M. L. (1999). A família e a escola marcando a formação do leitor. Thesis, Instituto de Psicologia, Universidade de São Paulo, São Paulo.

Mezan, R. (2002). Pode-se ensinar psicanaliticamente a psicanálise? In R. Mezan, A vingança da esfinge: Ensaios em psicanálise, pp. 187-204. São Paulo, SP: Casa do Psicólogo.

Ministério da Saúde. (1984). Assistência integral a saúde da criança: Ações básicas. Brasília, DF: author. Retrieved from http://bvsms. saude.gov.br/bvs/publicacoes/assistencia_ integral_saude_crianca.pdf

Ministério da Saúde. (2004). Agenda de compromissos para a saúde integral da criança e redução da mortalidade infantil. Brasília, DF: author. Retrieved from http:// bvsms.saude.gov.br/bvs/publicacoes/ agenda_compro_crianca.pdf

Myers, S. M., \&Johnson, C.P.(2007). Management of children with autism spectrum disorders. Pediatrics, 120(5): 1162-1182.

Nóbrega, M. F. B; Jorge, M. S. B; Valdès, M. T. M \& Silva, L. M. S. (2003). Formação do enfermeiro para detecção precoce de desvios psicomotores em lactentes - Fortaleza, estado do Ceará, Brasil. Acta Scientiarum. Health Sciences, 25(2), 183-190.

Oliveira,V.C;Cadette, M.M.M.(2009).Anotações do enfermeiro no acompanhamento do crescimento e desenvolvimento infantil. Acta Paulista de Enfermagem, 22(3), 301-306.

Ortiz, M. C. M. (2001). O lugar da mãe no tratamento do câncer infantil Dissertation. Instituto de Psicologia, Universidade de São Paulo, São Paulo, SP.

Pesaro, M. E. (2010). Alcance e limites teóricometodológicos da pesquisa multicêntrica de indicadores clínicos de risco para o desenvolvimento infantil. Tese de Doutorado, Instituto de Psicologia, Universidade de São Paulo, São Paulo.

Posternak, L. (2000). Alguns aspectos da prevenção pediátrica. Estilos da Clínica, 5(8), 170-177. 
Serrano, C. E. G. (2004). Eu mendigo: Alguns discursos da mendicância na cidade de São Paulo. Dissertation. Instituto de Psicologia, Universidade de São Paulo, São Paulo, SP.

Silva, P. R. M. (2002). A meninice (em casa) na rua: no limite da intimidade e da exposição da subjetividade no discurso. Thesis. Instituto de Psicologia, Universidade de São Paulo, São Paulo, SP.

Stein, R. E. K.; Horwitz, S. M.; Isser, A. S.; Heneghan, A.; Olson, L., \& Hoagwood, K. E. (2008). Do pediatricians think they are responsible for identification and management of child mental health problems? Results of the AAP Periodic Survey. Ambulatory Pediatric Association, 8(1): 11-17.

Souza, A. M. O. (2003). Loucura em cena: a "ambiência" como espaço informal de tratamento em um centro de atenção psicossocial. Thesis. Instituto de Psicologia, Universidade de São Paulo, São Paulo, SP.

Souza, A. N. (2001). Formação médica, racionalidade e experiência. Ciência \& Saúde Coletiva, 6(1):87-96.
Vasconcelos, E. N; Silveira, M. F. A; Eulálio, M. C; \& Medeiros, P. F. V. (2009) A normatização do cuidar da criança menor de um ano: estudo dos significados atribuídos pelos profissionais do Programa Saúde da Família (PSF). Ciência \& Saúde Coletiva, 14(4): 1225-1234.

Travieso, P. I. (2001). Os sujeitos no discurso jurídico das varas de infância e juventude: "Pedido de providências". Dissertation. Instituto de Psicologia, Universidade de São Paulo, São Paulo, SP.

Vechi, L.G. (2003). Marcas da iatrogenia no discurso de profissionais em hospital-dia. São Paulo, SP: Casa do Psicólogo.

Wanderley, D. B., Weise, E. B. P., \& Brant, J. A. C. (2008). O que há de avaliável no desenvolvimento infantil? Exame e discussão das escalas de avaliação de desenvolvimento infantil mais usadas no Brasil. In In R. Lerner \& M. C. M. Kupfer (Eds.). (2008), Psicanálise com crianças: Clínica e pesquisa (pp. 109-114). São Paulo: Escuta. 